\title{
天然高分子サプリメントに対する薬物の結合性評価
}

\author{
佐藤弘希 ${ }^{1,2}$, 丸山 徹 ${ }^{* 1,2}$, 荒平光利 ${ }^{1}$, 吉田 節 ${ }^{1}$, 前田敦司 ${ }^{1}$, \\ 桑原賢司 ${ }^{1}$, 岡山善郎 ${ }^{1}$, 山崎啓之 ${ }^{3}$, 安楽 誠 $^{2}$, 小田切優樹 ${ }^{2}$ \\ ファーマダイワ \\ 熊本大学大学院医学薬学研究部 ${ }^{2}$ \\ 宮崎大学医学部附属病院薬剂部 ${ }^{3}$
}

\section{Investigation of Binding of Drugs with Natural Polymer Supplements}

\author{
Hiroki Sato ${ }^{1,2}$, Toru Maruyama ${ }^{* 1,2}$, Mitsutoshi Arahira ${ }^{1}$, Setu Yoshida ${ }^{1}$, Atusi Maeda ${ }^{1}$, \\ Kenji Kuwahara ${ }^{1}$, Yoshiro Okayama ${ }^{1}$, Keishi Yamasaki ${ }^{3}$, \\ Makoto Anraku² and Masaki Otagiri \\ Pharma Daiwa Co., Ltd. ${ }^{1}$ \\ Graduate School of Medical and Pharmaceutical Sciences, Kumamoto University ${ }^{2}$ \\ Department of Pharmacy, Miyazaki Medical College Hospital ${ }^{3}$
}

$\left[\begin{array}{l}\text { Received March } 102005 \\ \text { Accepted July 2, } 2005\end{array}\right]$

In order to clarify the interactions between drugs and natural polymer supplements, the binding tendency of warfarin, ketoprofen and chlorpromazine with six kinds of commonly used natural polymer supplements-low molecular weight alginate, chitosan, guar gum degradation products, wheat albumin, dietary fiber derived from beer yeast and indigestible dextrinwere investigated by means of ultra-filtration. Though each of the drugs bound to the supplements, the degree of the binding varied largely with the different combinations of the drugs and the supplements. Specifically, acidic drugs showed significant binding with chitosan, which was probably due to electrostatic interaction. Binding between chitosan and warfarin was found to be dose-dependent and binding between all of the drugs and chitosan was found to vary with the type of chitosan product. In this regard, among widely available products, some hardly bound to the drugs at all whereas others bound very easily. These results suggest that the absorption of drugs could be inhibited when natural polymer supplements are taken simultaneously. Therefore, patients taking physiologically active drugs such as warfarin or TDM drugs should be instructed to avoid polymer supplements.

Key words — natural polymer supplement, drug binding, chitosan, warfarin

\footnotetext{
緒言

近年，サプリメントの利用者が急増している。サプリ メントは法律上，食品に分類されているため，安全，安 心といったイメージがあり，安易に利用されやすいが， 中には医薬品に近い生物活性を有するものも開発されて いる. そのため, 不適切な摂取や安易な医薬品との併用 は, 健康被害や疾病の悪化につながりやすく, 社会的な 問題となってきている。 これらの原因の一つとして，サ プリメントの適正な利用を支援するための専門家の不在 が指摘されている。すなわち, 消費者は, 曖昧かつ限局
}

された情報に基づき自己判断でサプリメントを利用して いる。このような危険な現状を危惧し，厚生労働省はサ プリメントに係る質の高いアドバイザリースタッフの必 要性を示している。このアドバイザリースタッフとして 薬剂師に対する期待は大きい1). サプリメントを適正に利用していくうえで，医薬品と の相互作用を回避することは最も重要な課題の一つであ る。しかしながら現状では, サプリメントと医薬品との 相互作用に関する情報は不足しており, 薬剂師が適切な アドバイスを行うには困難な状況に置かれている．加え て最近，わが国で開発されるサプリメントも急増してお り，海外の情報を活用できないケースも増えている。こ 
のような背景の下，われわれはサプリメントアドバイ ザーとして，サプリメントと医薬品の相互作用に関する エビデンスの構築に鋭意努力している.

ところで，薬物どうしの吸着や結合は，消化管からの 吸収を阻害することがあり，薬戍師がマネージメントす べき相互作用の一つに位置づけられている象。薬物間 の吸着や結合は, 両者の物理化学的および立体構造特性 に依存しているが, 特に活性炭製㓮 ${ }^{4)}$, コレステロール 吸着樹脂5,6), タンニン酸アルブミン ${ }^{7)}$ といった高分子医 薬品との併用で生じやすい.

食物繊維, 蛋白質, 糖類などの天然高分子は, 整腸, 血糖降下，脂質低下といった多様な機能を有しているた め, これらの多くは特定保健用食品としても繁用されて いる ${ }^{8,9)}$. しかしながら, 天然高分子サプリメントは, 上述した高分子医薬品と類似した物性を有しており，薬 物と同時に摂取すると, 両者間の吸着や結合により, 主 薬の吸収を阻害する可能性が懸念される. 加えて現段階 では，天然高分子サプリメントと医薬品との吸着や結合 に関する報告は少なく，特に市販の製品を用いた検討は ほとんどなく，サプリメントと医薬品との相互作用に関 する情報の集積が強く望まれる.

そこでわれわれは，天然高分子サプリメントと医薬品 との相互作用を明らかにすることを目的として，繁用製 品と薬物の結合性に関する検討を行い，得られた知見に 基づき薬剤師の果たすべき役割について考察した。

\section{方法}

\section{1. 試料}

サプリメントとしては，天然高分子を謳っている製品
の中から, 低分子化アルギン酸, キチン・キトサン, グ アーガム分解物, 小麦アルブミン, ビール酵母由来の食 物繊維，難消化デキストリンの 6 種類を用いた。表 1 に それらの特徵を示す。薬物としては, 酸性薬物として ワーファリン，ケトプロフェンを，一方塩基性薬物とし てはクロルプロマジンを用いた，その他，試薬，溶媒類 はすべて市販特級品を使用した。

\section{2. 試料の調製}

サプリメント一回摂取量 (メーカー推奨)を日局第 2 液 $100 \mathrm{~mL}$ に溶解後，薬物を最終濃度が $10 \mu \mathrm{M}$ になるように 添加し, 混合 ·振とう後, 試料溶液とした。また, 各種 サプリメントの濃度は, 上述した試料溶液をさらに日局 液で希釈して調製した。

\section{3. 薬物結合性評価}

薬物結合率は，限外ろ過キット(アミコン社製)を用い て評価した ${ }^{10)}$ 。なお，乃過膜としては分子量3000を用い た. 試料溶液 $1 \mathrm{~mL}$ をキットに充填し, $2000 \mathrm{rpm}, 37^{\circ} \mathrm{C}$ で40分間遠心後，遊離薬物量を高速液体クロマトグラ フィー(HPLC)により測定した。 HPLCは，日立655型可 変波長 UV モニター(株)日立製作所) および日立 L-7480 型蛍光検出器(株)日立製作所)により構成され，分析力ラ ムとして LiChrosorb RP-18 (Cica Merck)を使用した。移 動相は, ワルファリン ${ }^{11)}$ ，ケトプロフェン ${ }^{12)}$ およびクロ ルプロマジン13)において，30mM リン酸緩衝液 (pH7.7)アセトニトリル $(42.5 / 57.5, \mathrm{v} / \mathrm{v}) ， 0.2 \mathrm{M}$ 酢酸緩衝液 $(\mathrm{pH}$ 4.5)ーアセトニトリル $(60 / 40, \mathrm{v} / \mathrm{v})$ および $1.5 \%$ 酢酸緩衝 液 $(\mathrm{pH} 6.0)$-メタノール $(70 / 30, \mathrm{v} / \mathrm{v})$ をそれぞれ使用し た.ワルファリンは励起/蛍光波長 $(300 \mathrm{~nm} / 400 \mathrm{~nm})$ を,

表 1.今回用いた天然高分子サプリメントの特性

\begin{tabular}{|c|c|c|}
\hline 成分 & 機能表示 a & 特 徵 \\
\hline $\begin{array}{l}\text { 低分子アルギン酸ナト } \\
\text { リウム }\end{array}$ & $\begin{array}{l}\text { おなかの調子を整え } \\
\text { る食品 } \\
\text { コレステロールが高 } \\
\text { めの方の食品 }\end{array}$ & $\begin{array}{l}\text { 海藻由来の水溶性食物緎 } \\
\text { 維 } \\
\text { カルボキシル基を有する }\end{array}$ \\
\hline グアーガム分解物 & $\begin{array}{l}\text { おなかの調子を整え } \\
\text { る食品 }\end{array}$ & $\begin{array}{l}\text { マメ科植物グアーの種子 } \\
\text { を加水分解した多糖 (ガ } \\
\text { ラクトマンナン) }\end{array}$ \\
\hline キトサン & $\begin{array}{l}\text { おなかの調子を整え } \\
\text { る食品 } \\
\text { コレステロルが高 } \\
\text { めの方の食品 }\end{array}$ & $\begin{array}{l}\text { 甲款類の殼に含まれるキ } \\
\text { チンを脱アセチル化した } \\
\text { 多糖 } \\
\text { アミノ基を有する }\end{array}$ \\
\hline 小麦アルブミン & $\begin{array}{l}\text { 血糖值が気になりは } \\
\text { じめた方の食品 }\end{array}$ & $\begin{array}{l}\text { 小麦中の水溶性たんぱく } \\
\text { 質 } \\
\text { アミラーゼ阻害作用を有 } \\
\text { する }\end{array}$ \\
\hline $\begin{array}{l}\text { ビール酵母由来食物 繊 } \\
\text { 維 }\end{array}$ & $\begin{array}{l}\text { おなかの調子を整え } \\
\text { る食品 }\end{array}$ & $\begin{array}{l}\text { ビール酵母の細胞壁に含 } \\
\text { まれる難消化性の多糖 }\end{array}$ \\
\hline 難消化性デキストリン & $\begin{array}{l}\text { おなかの調子を整え } \\
\text { る食品 } \\
\text { 血糖值が気になりは } \\
\text { じめた方の食品 }\end{array}$ & $\begin{array}{l}\text { でん粉をアミラーゼで処 } \\
\text { 理した水溶性食物繊維 }\end{array}$ \\
\hline
\end{tabular}

$\mathrm{a}$ ：特定保健用食品で使用されている機能表示 
ケトプロフェン，クロルプロマジンは UV モニターによ り，それぞれ，220nm，280nm を測定した。 なお，各薬 物の測定キットへの吸着は無視できるものであり，全薬 物濃度 $(\mathrm{Ct})$ に対する遊離型薬物濃度 $(\mathrm{Cf})$ 比から, 下記の 式に従い結合率を算出した。

結合率 $(\%)=100-($ 遊離型薬物濃度 $(\mathrm{Cf}) /$ 全薬物濃度 $(\mathrm{Ct}) \times 100)$

\section{結果・考察}

サプリメントの利用者の急増に伴い，サプリメントと 薬物の相互作用が懸念されるようになってきた。中で も, サプリメントに対する薬物の結合や吸着は, 治療薬 の吸収を阻害する可能性があるため, 薬剤師によるマ ネージメントが重要となってくる相互作用の一つであ る.それにもかかわらず，高分子サプリメントと薬物の 吸着や結合に関する検討は少なく，これまでのところ， サイリウム種子由来繊維物へのリチウムの吸着, 小麦ふ すま，ポリデキストロース，ガラクトマンナン，低分子 アルギン酸ナトリウムに対する鉄剤, 強心剤, 脂溶性ビ タミンの吸着・結合などしか報告されていない ${ }^{14-16)}$.

今回，ワルファリン，イブプロフェン，クロルプロマ ジンをモデル薬物に，6種の繁用されている天然高分子 サプリメント(低分子化アルギン酸, キチン・キトサン, グアーガム分解物，小麦アルブミン，ビール酵母由来の 食物繊維，難消化デキストリン) との結合性を限外ろ過 法により検討した、いずれの薬物もサプリメントに結合 したが，その程度は薬物とサプリメントの組み合わせに より大きく異なっていた(表 2 ). ワルファリンの場合， キトサンに対する結合率が最も大きく，次いで難消化デ キストリン, 小麦アルブミンの順であった。 ケトプロ フェンも，ワルファリンと同様，キトサンに対する結合 が最も強く, グアーガム分解物や小麦アルブミンに対し ても結合性が認められた。他方, 塩基性薬物であるクロ ルプロマジンの場合，キトサンに対する結合が観察され たが，その程度は酸性薬物に比べると低かった。一般
に, リガンドは高分子の疎水領域, 小孔, 電荷, マト リックスヘ, 疎水相互作用, ファンデルワールスカ, 水 素結合, 静電的相互作用, などの分子間力で可逆的に結 合する ${ }^{17)}$. 今回の薬物およびサプリメントもそれらの分 子中に疎水領域を有していることから, 結合過程に疎水 性相互作用やファンデルワールスカなどの分子間相互作 用が関与していると思われる。一方, キトサンと酸性薬 物との結合が，他に比べ顕著であったことから，さらな る分子間力の関与が推察される。キトサンは N-アセチ ルーDーグルコサミンが $\beta(1-4)$ 結合したキチンからア セチル基を外した天然多糖であり，分子中に遊離のアミ ノ基を多数有している ${ }^{18,19)}$. このキトサンに対する低分 子化合物の吸着様式は Langmuir 式に従う単分子層吸着 であることが明らかにされている20). また，その反応に は分子中のアミノ基が重要な役割を果たしており, 吸着 量はアミノ基の含量に依存するという知見も報告されて いる ${ }^{21,22)}$. したがって，今回キトサンで観察された有意 な結合性も特異的なものというよりは，むしろ非特異的 な吸着反応ではないかと推察される。また，キトサンが 酸性薬物に対して高い結合性を示したことから，結合過 程には疎水性相互作用やファンデアワールスカに加え， キトサン分子中のアミノ基を介する静電的相互作用や水 素結合も重要な役割を果たしている可能性が示唆され た。

ワルファリンは個々の患者において細かい用量設定を 必要とする代表的薬剤である。このようなタイプの薬剤 では, 薬物の結合による吸収阻害の程度が低くても, 結 合量が用量の調節分に相当することがあり，臨床上の問 題となりやすい. そこで，ワルファリンを対象として， キトサンとの相互作用に及ぼす要因について検討を加え た。まず，キトサンとワルファリンの相互作用における 用量依存性について検討したところ，両者の結合は用量 依存的であり，キトサンの希釈倍率の増加に伴いワル ファリンの結合性は減少した(図 1 )。このことは，キト サンの摂取量が増加すると, ワルファリンの吸着量も増 加する可能性を示している。なお，今回は薬物濃度を変

表 2. 各種サプリメントに対する薬物の結合性

\begin{tabular}{cccc}
\hline & \multicolumn{3}{c}{ 結合率 $(\%)$} \\
\cline { 2 - 4 } & ワルファリン & ケトプロフェン & クロルプロマジン \\
\hline 低分子化アルギン酸ナトリウム & $7.3 \pm 0.9$ & $1.3 \pm 3.5$ & $2.6 \pm 1.1$ \\
グァーガム分解物 & $1.9 \pm 1.9$ & $20.8 \pm 5.8$ & $3.6 \pm 2.1$ \\
キトサン & $65.6 \pm 4.2$ & $83.1 \pm 0.8$ & $29.3 \pm 0.2$ \\
小麦アルブミン & $34.6 \pm 1.5$ & $11.6 \pm 0.4$ & $2.6 \pm 1.5$ \\
ビール酵母由来食物繊維 & $2.0 \pm 1.2$ & $1.76 \pm 0.8$ & $3.8 \pm 2.1$ \\
難消化性デキストリン & $23.0 \pm 7.1$ & $25.5 \pm 1.6$ & $3.4 \pm 1.1$ \\
\hline
\end{tabular}

$(n=5$, mean $\pm S D)$ 
化させた検討は行っていない. 今後，この点に関しては 定量的な評価を行い, 結合パラメー夕を求めていく予定 である。

一般に，サプリメントは医薬品に比べ製造過程や品質 管理に関する規制が厳しくないため, 製造メーカー毎に 製法が異なることもある。 その結果, 同じサプリメント であっても，有効成分の含量や精製度，あるいは不純物 の混入度などがメーカーにより異なることがある. 当然 のことながら，このような製品間のばらつきは薬物の吸 着や結合にも影響を及ぼすことが懸念される.そこで次 に，キトサンとワルファリンの吸着に及ぼす製品間の違 いについて検討した(図 2 )。ここで，キトサン製品とし ては，ラベルから有効成分としてキトサンのみを含有す るものを 6 種類選択した。図 2 に示すように，ワルファ リンの結合性は製品間で大きく異なっており，ほとんど 吸着しない製品から非常に吸着しやすいものまで市販さ れていることが判明した。 キトサンの場合，原材料とな るキチンを脱アセチル化して精製する。このことから， 製品間で観察された結合性の差異の一因として, 脱アセ チル化度の違いが影響している可能性が推察される。も しそうであれば，これらの情報に基づき相互作用の程度

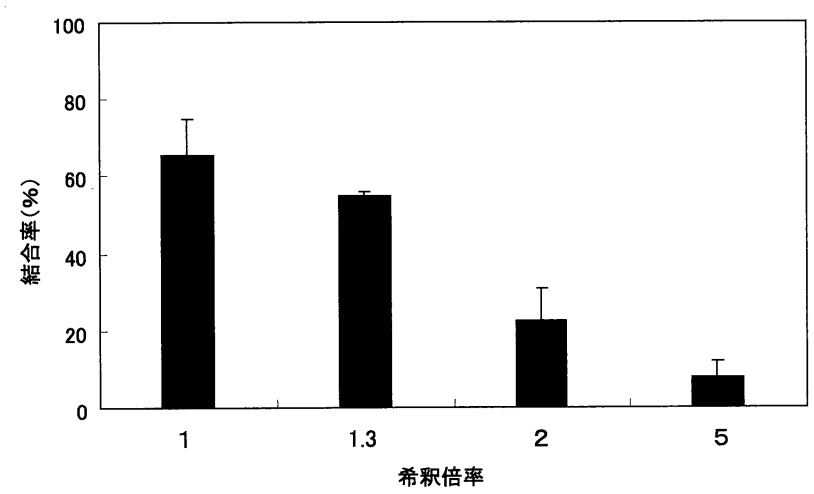

図 1. 各種キトサン希橎液に対するワルファリンの 結合性

$(\mathrm{n}=5$, mean $\pm \mathrm{SD})$

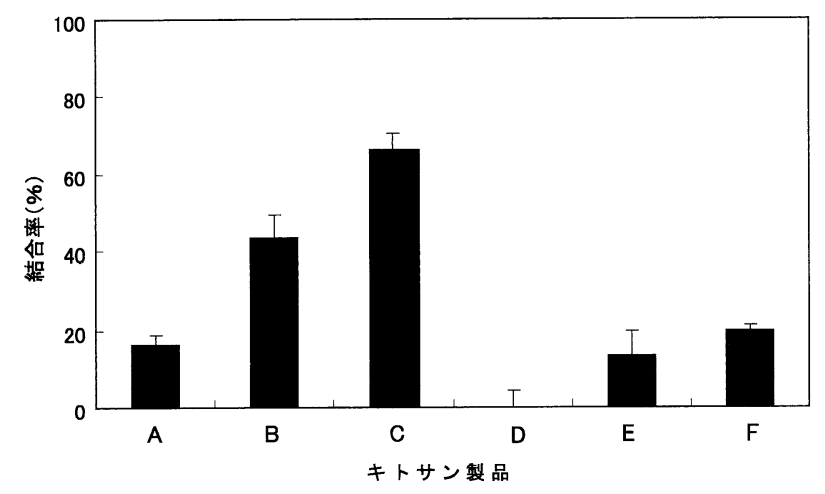

図 2.キトサン製品間でのワルファリン結合性の 変動

$(\mathrm{n}=5$, mean $\pm \mathrm{SD})$
を予測できるかもしれない. そこで，各製品の脱アセチ ル化度や分子量分布について製品ラベルや製造メーカー から調査を試みたが，残念ながら十分な情報を得ること ができなかった。このことは，言い換えれば，製品情報 からキトサンとワルファリンとの結合の程度を予測する ことが困難であることを意味している，また，添加物の 種類と含有量の違いが結合性に影響を及ほした可能性も 否定できない.

今回得られた知見にもとづき，サプリメントと薬物の 結合・吸着反応に対する薬剤師のマネージメントについ て考察した。一般に, 薬物間の吸着では, 両薬郕の服用 間隔をずらすことにより回避できることが多い2,3). 当 然ながら，サプリメントと薬物の場合も同様な対処方法 で回避することは可能であろう。しかしながら，今回検 討した天然高分子サプリメントの場合，食後の利用でそ の効果を発揮するものが多く ${ }^{8,9)}$, 相互作用を回避する ためには，まずサプリメントを食後に摂取し，それから $1 〜 2$ 時間ほどして薬物を服用することになる．このよ うな複雑な服用指示の結果, 最も優先すべき治療薬のコ ンプライアンスが低下し，期待した治療効果が得られな くなる可能性も懸念される.

一方，吸着性がほとんどない製品を選択することも相 互作用を回避するための有効な対応である。しかしなが ら，上述したように，サプリメントの製品情報から薬物 の結合や吸着性を予測することは非常に困難である．加 えて，今後も新たな天然高分子素材を利用した製品や， 複数の成分を組み合わせた商品が登場してくるであろ う.このような状況下では, 個々のサプリメント商品と 薬物の組み合わせを考慮して相互作用をマネージメント する個別な対応は効率的ではない。つまり，薬剤師は薬 物療法中の患者に対しては, 安全性の観点から，天然高 分子サプリメントの利用を避けるように指導すべきであ ると思われる。特に，ワルファリンや抗がん剂のように 生理活性の高い薬物, 免疫抑制剤といった TDM 対象薬 物のように，相互作用によるデメリットが大きいケース では摂取を避けるべきである，逆に，高分子サプリメン トの利用を希望する消費者に対しては，併用薬をきちん とフォローしておくことが重要である。ただ，処方内 容によっては食後の服用が必要ないケースも存在する. このようなケースでは, 薬物を服用していない時期を選 んで高分子サプリメントを利用することは可能かもしれ ない.

上述した知見はあくまでも in vitro という非常に単純 な条件での検討結果である．生体では，食事の有無や胃 酸, 胆汁酸をはじめとする消化液の存在などといった 種々の要因が複雑に関与しており，今回の結果をそのま ま当てはめることはできない. 今後，この点に関して

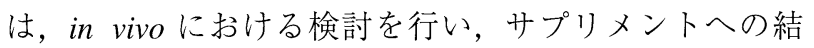


合が薬物の吸収過程にどの程度影響を及ぼすのかを明ら かにしていくことが必要である。ただし，現時点ではサ プリメントの摂取による薬物吸収への影響が完全に否定 できないため，上述したようなマネージメントが必要で あると思われる。また最近，栄養管理の重要性が見直さ れ，医療の場においても各種食物繊維が活用されてきて いるが，これらの機能性成分に対する薬物の吸着性に関 する検討はほとんど行われていない. 今後, サプリメン 卜に加え，これらの栄養成分に関しても相互作用の可能 性を明らかにしていくべきであろう。

\section{引用文 献}

1) 石見佳子, サプリメントの法的規制, サプリメント の使い方・選び方一統合医療における薬郕師の役 割, 薬局, 55, 9-14 (2004).

2）澤田康文，薬の消化管吸収と相互作用，薬局，52, 131-147 (2001).

3）澤田康文, 処方せんチェック 消化管吸収と相互作 用, 薬局 8 月号別冊, 55, 176-255 (2004).

4) C. Tanaka, H. Yagi, M. Sakamoto, Y. Koyama, T. Ohmura, H. Ohtani, Y. Sawada, Decreased phenobarbital absorption with charcoal administration for chronic renal failure, Ann. Pharmacother, 38, 73-76 (2004).

5) M.A. Young, S. Lettis, R. Eastmond, Concomitant administration of cholestyramine influences the absorption of troglitazone, Br. J. Clin. Pharmacol., 45, 37-40 (1998).

6) W. Muck, W. Ritter, R. Frey, N. Wetzelsberger, P.W. Lucker, J. Kuhlmann, Influence of cholestyramine on the pharmacokinetics of cerivastatin, Int. J. Clin. Pharmacol. Ther., 35, 250-254 (1997).

7) 旭満里子, 中島恵美, 市村藤雄, 薬物間相互作用と 医薬品適正使用, 月刊薬事, 2 月臨時増刊号, 38, 441-450 (1996).

8）堀美智子, 薬剂師と栄養士連携のためのサプリメン トの基礎知識, 薬事日報社, 東京, 2002, pp. 95-220.

9）山口宏二，サプリメントアドバイザー必携，日本サ プリメントアドバイザー認定機構編集, 薬事日報 社，東京, 2003, pp. 104-123.
10) 小田切優樹, “薬物のタンパク結合実験法”, 小田切 優樹, 杉山雄一編, 廣川書店, 東京, 1991, pp. 23-62.

11) K. Yamasaki, T. Maruyama, U. Kragh-Hansen, M. Otagiri, Characterization of site I on human serum albumin : concept about the structure of a drug binding site, Biochim Biophys Acta., 1295, 147-157 (1996).

12) M. Anraku, K. Yamasaki, T. Maruyama, U. KraghHansen, M. Otagiri, Effect of oxidative stress on the structure and function of human serum albumin, Pharm. Res., 18, 632-639 (2001).

13) K. Matsumoto, K. Sukimoto, K. Nishi, T. Maruyama, A. Suenaga, M. Otagiri, Characterization of Ligand Binding Sites on the $\alpha_{1}$-Acid Glycoprotein in Humans, Bovines and Dogs, Drug Metab Pharmacokinet, 17, 300-306 (2002).

14) A. Fugh-Berman, Herb-drug interactions, Lancet, 355, 134-138 (2000).

15）山崎大治, サプリメントの正しい使い方, New Diet Therapy, 20, 29-40 (2005).

16) M. Toutoungi, P. Schulz, J. Widmer, R. Tissot, Probable interaction of psyllium and lithium, Therapie, 45 , 358-360 (1990).

17) D. Freifelder, Physical Biochemistry: application to biochemistry and molecular biology, Freeman and Company, New York, 1982, pp. 653-684.

18）吉本宏, 鉄川歩, 斉藤純一, 長田嘉穂, キトサンを 利用した経口吸着剤，キチン・キトサン研究，1，16 (1995).

19) L. Illum, Chitosan and its use as a pharmaceutical excipient, Pharm. Res., 15, 1326-1331 (1998).

20) M.S. Chiou, W.S. Kuo, H.Y. Li, Removal of reactive dye from wastewater by adsorption using ECH crosslinked chitosan beads as medium, J. Environ Sci. Health A Tox Hazard Subst Environ Eng, 38, 26212631 (2003).

21) X. Zhang, R. Bai, Mechanisms and kinetics of humic acid adsorption onto chitosan-coated granules, J. Colloid Interface Sci., 264, 30-38 (2003).

22) M. Thongngam, D.J. McClements, Influence of $\mathrm{pH}$, ionic strength, and temperature on self-association and interactions of sodium dodecyl sulfate in the absence and presence of chitosan, Langmuir, 21, 79-86 (2005). 